大上り，林樆大位に至る迄あると報告されてる るが，本症例も沜卵大である。

此の血腫に化り，臍帶血管循環飞變化を及ぼ すことは, 當然であり, 其の爲胎兒の生命を奪 ふことは考へられるのである。本症例に於て は, 高度の捻轉, 外傷, 血栓形成も見出されな かつたが，恐らく，臍帶の二重纆絡に依る强い 牽引が原因し, 翢帶靜脈の破裂を來たし, 血腫
を形成し，それが胎兒死亡の原因となつたもの と思はれる。

結語、私は24才 2 ケ月の初産婦の骨盤位分婏 に於ける胎兒死亡例飞於て, 該胎盤の臍帶附着 部に血腫あるを認め, 其が稀有なる臍帶血腫な ることを知り，弦に報告した次第である。終り に臨み, 直接御指導下されし, 本學真柄敎授, 慈惠醫大，樋口教授に深甚の謝意を表す。

\title{
先天性十二指腸閉塞症の一例
}

\section{A Case of Congenital Duodenal Obstruction}

\begin{abstract}
日本知筑學三篦院産婦人科
罃學士田邊 三 郎

Tanabe, Saburo.
\end{abstract}

\section{內 容抄錄}

私は28歳, 初産婦で妊娠末期に羊水過多症を 伴ひ, 出生後珈琲殘㴡樣物を吐出しつつ, 第 6 日目死亡した體重 2,150 瓦の, 一女性新産兒 剖檢し，其の死亡原因が十二指腸部の先天性膜 樣閉塞依るものであることを發見した。何其 他の臟器に於ても左警胞腎, 左肺分葉不全等の 渏形老認めた。

\section{緒言}

先天性の 腸管狹窄乃至 閉塞は稀な 畸形であ る。Cllogg (1904) は乳兒 11000 人中 2 例芷發 見するに過ぎなかつた言ふ, 三谷氏は日赤産 院に於て, 新産兒剖檢例 650 中例 5 發見した。 泉橋病院に於て久保田, 泉田兩氏は大正14年か, ら，昭和10年に至る11年間の外來患者 49000 人 中，2例を發見するに過ぎなかつたと言ふ。實 際小兒科方面に於ては，多くは狹窄の所見であ り, 完全閉塞の場合は多くは生後十日以内に死 の轉歸をとるものである。本邦小兒科方面に於 ては小山, 岩川, 久保田, 中村, 伊藤, 村上, 田, 泉田, 稻葉, 飯淵, 富田等の報告がある。
岩川, 中村, 伊藤, 田, 飯淵, 富田, 氏等の例 は剖檢に传つて明らかにされたものである。近 藤, 野副, 森本, 長島, 加藤, 氏等の例は, 何 れも手術例であるが, 豫後は皆不良であつた。 手術療法は其の技術の如何よりは腸管蠕動の有. 無隹つて決定せらるるものであつて, 膜樣閉 塞の如き簡單な閉塞であつても結果は期待し得 られぬものである。また本症の豫後を良くする ためには，早期に發見し之の狹窄乃至閉塞の部 位が, 消化管の何れの部位に存在するか, 及び 其の閉塞の狀態を知る事が肝要である。然るに 閉塞部以下の腸管の狀態は「レ線に依るも全く 推知し得ないものである。依つて兒の胎内に於 ける狀態が，極めて良い診斷の寥考となる場合 がある。

先天性十二指腸閉塞症に, 羊水過多症を伴及 事の多いことは, 夙に認められた所で, 就中本 學三谷茂㸚授は, 昭和1.5年先天性十二指踼閉塞. 症に於て, 妊娠中羊水過多症が早期に發生し, 且つ多量なる際は閉塞は早期に發生し十二指腸 部は盲端に終吅るのであつて, 羊水過多症の 發生层く, 且つ羊水の增加の少ない際には膜樣. 閉塞なりと說かる。此の閉塞部が盲端に終るか 
或ひは膜樣閉塞であるかは手術を行ふ上に重要 なる意義を有するすのであつて，私の例於け る閉塞の形態も，發生の時期8全〈三谷教授の 說に適合して居るのを認めた次第である。

\section{症例}

母

28 藏 初産婦

家族歷 父母健 同胞 3 人健 良人健。 産婦既往歴 幼期健 27 歳 1 月右側肋膜炎、 飞篗患, 初經來潮, 16 歳 2 月, 整, 4 日間, 中 等量, 障礙なし, 其他著患を知らす。結婚 26 歳 12月。

妊娠經過。最終月經, 昭和 24 年 5 月 2 日より 4 日間, 7 月初旬上り惡阻症狀离り, 初診昭和 24 年 7 月 8 日, 初診時所見, 子宮は强度飞前屈

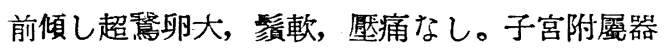
仕觸れす, 腔は硬靶平滑, 診斷, 妊娠 3 ケ月, 分婏豫定日昭和 25 年 2 月 9 日。ワッセルマン氏 反應, 村田氏反應共江陰性。

9月29日, 再診, 胎動は未代感知せす, 子宮

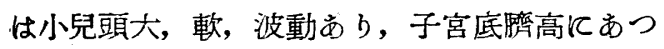
て17框，兒の位置未だ不明，兒心音は中央線に 於て著明, 浮腫なし, 血壓96一60。

11月 8 日再診, 1ケ月前よb胎動を感知す, 子宮底䏦上 2 指横徑 (23糎) 胎兒の大部分は右 側飞觸知す, 兒心音は右瞊棘腺に於て衤取す下 肢に輕度の浮腫あり, 膝蓋腱反射は減退, 血壓 120一88, 尿中蛋白輕度陽性。

11月 14 日再診, 子宮底臍上 2 指横徑 24 糎, 腹 壁は相當緊張す，兒頭は骨盤入口上に在るもの

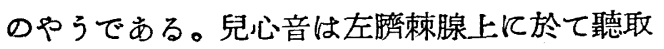

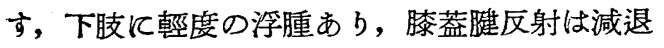
し, 血壓 102-64, 尿中蛋白痕跡陽性。

12 月 2 日再診, 子宮底帟上 3 指横徑 25 数, 兒 頭骨盤入口上を移動し，兒心音は右臍棘腺上飞 整調なるも, 微弱に聽取す。下肢《輕度の浮腫 あり，尿中蛋白陽性。

12月19日再診, 子宮底脇上 3 指横徑 25 粧, 兒 頭は骨盤入口上飞浮游す, 兒心音は右脇棘腺上 に於て, 整調なるも微弱に聽取す。下䁌に中等

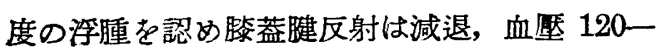

82 ，尿中蛋白陽性。

12 月29日再診, 子宮底劍狀突起下 2 指横徑, 34 糎, 兒頭は骨盤入口上に浮游す。兒心音は右 臍棘腺上に整調に聽取す, 子宮は球狀汇緊張し 波動著明であり，下肢に中等度の浮腫あり，膝 蓋腱反射は正常尿中蛋白陽性, 前回診察日上り 10日を經過して急に羊水過多を證明するに至つ t。

分婏經過。昭和 25 年 1 月 9 日夜半腹部膨滿の 䉆, 胸部壓迫感, 呼吸困難, 涉鲉度の陣痛ら しきものを許へて大院に及ぶ。

1月10日入院時所見。广宮底 43 粝, 子宮は球 狀で緊張し波動著明である。兒の位置及び兒心 音は不明, 下腹部に中等度の浮腫を認め, また 下肢にも輕度の浮腫あり, 子宮頸管は 3.5 指横 徑援張胎胞は輕度沉緊張し, 先進部は頭部の如 く思はるるも,陣痛らしきものは認められない。 午後 8 時 30 分再診時所見は前回と大差なく依然 陣痛は認められす，午後10時陣痛催進の目的を 以て「ビツイトリン」0.2cc を注射するも陣痛 顯著とならす，胸部の苦悶を訴人たので $20 \%$ 葡 萄糖 $50 \mathrm{cc}$ 党注射す。午後11時洗腸少量の便通 あり。

1月11日午前 8 時低然陣痛强くならす, 所見 は前回と同樣であつたので，子宮頸管を用手的 に開大を試みた。午後 8 時55分頃頸管は略全開 大凡近くなったる、も，陣痛は不規則且つ微弱で あり, 胎胞は强度に緊張す。陣痛催進の目的を 以て人工破水を行ひ約 $1.000 \mathrm{cc}$ の黄色透明なる 羊水を排出す。兒心音は中央線に於て著明汇聽 取し得たが, 午後 9 時 13 分頃には不整となり 8 , 7,9 , となつたので, 鉗子手術に依り午後 9 時 24 分女兒を第二後頭位で婏出せしめた。後産婏出 は午後 9 時30分羊水全量は約 $3,500 \mathrm{cc}$ 出血量 $200 \mathrm{cc}$ である。臍帶長さ 76 糎, 太さ 0.7 糎, 捻轉左, 附着側方。胎盤, 形圆形, 大さ $18 \times 17$ 厚さ 1.5 糎, 裂孔邊綵, 石灰沈着なし, 分葉著 明其他異常所見は認められない。

母體産裖經過經過良好であり, 産裖7日目無 事退院した。

新産兒所見。兒は女性, 體重 2.150 瓦, 身長, 
$-68-(840)$

50 糎, 坐高 22 粝, 肩幅 10 糎, 胸幅 9 糎, 腰幅 8 糖。

新産兒臨床經過。第一日,體温 $35.7-36.4$ 度 排尿は 2 回ありたるも，胎糞の排泄なく，5\% 菊萄糖50cc，「ビタミン」B，C，「プレホルモ ン」100單位注射す，第二日，排尿排便なし，第 一回嘔吐午前 1 時黄色水樣液以後, 珈琲殘渣樣 物を少量づつ 5 回嘔吐す, 鼻出血むり, 體温 35.4 - 36.0 度，5\%葡萄糖 $50 \mathrm{cc}$ 「ビタミン」B，C を注射す。

第三日。排尿 2 回，便通なし。嘔吐數回，吐

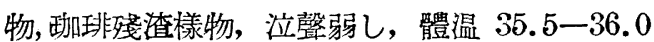
度, 輕度の黄疽を認む。 $5 \%$ 葡萄糖 $50 \mathrm{cc}$ 「ビタ ミン」B，C「カチーフ」1cc「カンフル」油

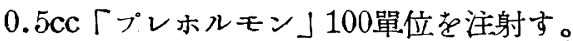

第四日。嘔吐を認めす。殆んど泣かす，胸部 は異常なく腹部は下腹部にが緊張し，中等篦 の膨隆を認め，また外除部，肛門等は正常で外 陰部より少量の白色粘液の出づるを認め, また 「グリセリン」浣腸を行ふる綠白色の粘液が少 量排泄されたるのみで, 胎䔬樣のものを認めす, 體温は 36.5-35.4 度, 排尿 2 回, 排便なし。 尿「グメリン」反應陽性，處置前日と同核。

第五日。嘔吐 3 回, 排尿, 排便なく吸啜力は 全くなく，昆睡狀態で體温最高 37.5 度。

第六日。前日と同じ昆睡狀態で午前 6 時10分 遂に死亡するに至つた。

剖檢所見 (死後 28 時間50分)

體格小，瘦削した一新産兒女性屍體，皮属は 貧血し輕度の责疽を認さ。屍班を認めす。外表 に睮型晎常を認めす。胸腹の正中線を開くに, 胸腹腔中に何等の液體の潴溜を見す，腹膜は滑 濢にして異常所見はなし。

胃は正常なる位置に於て稍々膨隆してるる， 之と連緢して同じく胃の形態を示し，然も胃よ りも大なる膨隆部が胃と並列して右より左前方 に走るのが認められる。之は十二指腸部の著し く膨蔽せるものであつて, 其他の小腸は正常な る形態を有するけれども，何等空氣の通過した る膨隆の所見を認める事が出來ない。また横行 結腸が約11粝の長さに於て十二指腸膨隆部の下
緣は輕度に庱着する部分のあるのを認める。 肳骨及び胸骨に巽常なし。肋膜腔に異常なし。 心臟，形態，大さ尋常。重さ14瓦，心尖は左 室に依り形成せられる。左右心室，心房異常な

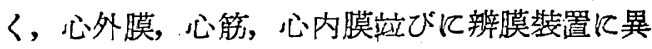
常なし。左肺臟大さ $5.1 \times 4.3 \times 2.1$ 糎，重さ 24 瓦上下肺葉間は僅かに截痕を認めるのみで連緦 す。表面滑濢, 硬度尋常, 肺門部淋已腺の腫張 なし。右肺臟，大さ $6.0 \times 7.0 \times 2.0$ 频厘重さ 30 瓦 分葉に異常なく，其他の所見左肺に同し。

肝臟, 大さ $7.4 \times 6.1 \times 3.2$ 糎, 形態尋常, 重 さ 86 瓦, 黑紫色, 表面滑㳯, 硬度軟, 割面血量 亿富み溷濁す。

膽褧㮐肥大し粘膜飞暴常なし。

脾臟大さ $4.3 \times 2.1 \times 1.1$ 糎, 重さ 7.5 瓦, 被 膜は緊張す。黑紫色, 硬度尋常, 割面䟤血高度, 脾材淋巴濾泡の像著明ではない。

左腎臟，大さ $3.7 \times 2.5 \times 1.8$ 糎，重さ 18 瓦硬 度顿, 被膜の剥離は容易であつて割面は皮質䯣 質等の割面の形態を全く認めすして粘液を含む 大小數個の䨳胞を以つて形成せられ, 所謂襄胞 腎の形態をなしてるるのが認められる。

腎孟，輸尿管は全く認められない。

右腎臟大さ $3.9 \times 2.5 \times 1.9$ 粝，重さ13瓦形態 尋常, 硬度尋常, 被膜の剝離容易にして割面皮、 質髓質の境は明瞭であり, 腎孟, 輸尿管にも異 常なく尋常なる形態である。

左副腎，大さ $3.0 \times 1.8 \times 1.1$ 糎重さ 2.5 瓦， 割面異常なし。右副腎, 大さ $1.5 \times 0.5 \times 0.35$ 粧 重さ 0.5 瓦，所見左副腎江同じ。

胃, 稍々演張し形態は尋常なるも幽門部は正 常なるものに比して稍擴張せるを認め上下徑， 5.9 糎, 左右徑3.7糎, 粘膜は粘液を以つて被仙 れ，多數の糜爛面を認むる事が出來る。

脺臟, ‘大さ $4 \times 1.5 \times 0.5$ 糎, 重さ 2 瓦, 形態 尋常, 硬度尋常, 割面異常なし。

十二指腸, 上下徑 5.8 糎, 左右徑 7.8 輝, 著 しく膨脹し暗綠色を呈し, 胃幽門部に連接し球 狀膨隆しつょ，胃の下緣に接して左に走り， 此の膨隆部の端上り, 直ち亿表面は尋常なる形 態を持てる, 空腸飞移行す。此の移行部は外表 
面は全く異常なきす, 其の内腔は十二指腸粘膜 と全く同じ莫に依つて中斷せられて, 空腸内膑 と隔離せられ, 此の閉塞に依り十二指腸部が膨 張するに到つたものである事が判る。割を加ふ るに多量の珈琲殘查樣物, 及び黄褐色溷濁液を 認め, 粘膜は異常なく殆んど横㱀譬を認めす。 幽門輪より約 4 糎下方に於て十二指腸乳頭の如 き部位を認め, 輸喏管開孔部と思はるっ孔あ ๖。小腸には小量の黄綠色粘液の内容を有し迴 盲部は移動し結腸にも黄綠色粘液樣物を容れ, 小腸と殆んど同樣の形態を示し胎䔬は認められ ね。

膀胱は少量の尿を容れ粘膜異常なし。

子宫及び附屬器は尋常なる大さ形態を有し異 常なし。

舌, 口腔, 食道に異常なし。 剖检的診斷

（1）十二指腸下部の膜樣閉塞㳖る十二指腸 の高度なる擴張。

（2）左腎臟の雴胞性變化。

(3) 左肺の分葉不全。

(4) 胃粘膜の糜爛。

主要臟器の組織的所見

心跀，左室壁を檢するに心筋の横絞は著明な らす，核の染色性甚だしく減退し，一般に毛細 血管の箖血著明にして, 其の周圍汇少量の出血 が見られる。

肺臟肺胞仿肋膜下に近き部分は援張不充分な る部位あるも, 肺胞の像一般に著明, 所によりて 膨大した肺胞内に肺胞上皮の如きものを充滿す るあり，また白血球汇少量の赤血球を含むもの にて充滿された所謂脑炎像が見られる。大なる 血管及び肺胞壁毛細血管共節血著明にして, 血 管周圍江出血贯も見られる。氣管枝は充分擴張 せる像を示し, 所によりては全く粘膜上皮の認 められぬ所がある。また氣管枝粘膜の剥離した 所もある。また内腔には少量の赤血球を認める ชのもある。

肝嘘, 皮膜に著變なし, 肝小葉の像ば大部分 著明にして旰細胞索の配列も明瞭なれぞも肝細 胞個々の境堺は不明瞭である。原形質は明瞭な
る部と不明瞭なる部とあり。又肝細胞核に著變 なし。毛細膽管の像は認むる事が出來す，毛細 血管は稍々擴張し, 星艺細胞に異常はない。

脾臟, 被膜に著變なし。脾小結節は周圍と明 瞭㴓し限局して小となり。中心動脈潩常な し。脾䯝は極めて增加せる像を示し一般に血液 量に富さ。脾洞は僅かて認さる事が出來る。

左腎臟, 褧胞腎をなせるものであつて被膜は 肥厚す。皮質は結締織が大部分を占め, 其の間 に大小不正形の䚻胞を形成せられたものを見 る, 震胞壁は扁平な上皮性細胞で被れ, 内容は 見られぬ，また「マルピキー」氏小體は諸所に 僅かに認め得るのみであつて, 曲細尿管も稀に 認め得るのみである。髓質と思はれる部分も亦 極めて吡血せる弓形動脈と大部分結締織より成 り，直細尿管は殆ど認める事が出來ない。

右腎臓, 被膜に異常なし, 髓質, 弓形動脉が 稍々䇺血せる外著變な認めす。

左副腎, 被膜は肥厚す。皮質, 㲑狀層, 束狀 層, 網狀層とも明瞭に認められ著變なし。髓質 部には著明なる微慢性出血を認める。

右副腎, 所見左副腎と大差なし。

胃, 䠣膜に異常なし, 筋層汇異常なし。粘膜 筋板に異常なく, 腺樣構造は大部分菲薄にして 上皮には異常は認められぬ。

十二指腸及び開塞部, 粘膜に付ては輪狀譬及 び固有板を全く認めす，ブルンネル氏腺明瞭な ๖。淋巴小結節は諸所飞認め, 粘膜下組織は明 瞭江認めうる。内輪筋層付諸所に認められざる 部分あり, 或は極めて菲薄となりたる部分を認 さ。然して中絶膜樣物は外縱筋層苍經て結締織 に依り空腸部に連續するのが見られる。

$$
\text { 總括 }
$$

先天性十二指腸閉塞症は畸形學上稀に見るも のとせられ諸外國に於て Theremin Schilegel Tandler, Forsner 氏等に依りて報告せられ， 本邦几於ては池田嘉一郎（大正 4 年）大梘菊雄 （大正12年）中村政治（昭和 4 年）伊藤辰治 (昭和 6 年) 館繁雄 (昭和14年) 稻葉實 (昭和 16年) 近藤俊平 '(昭和18年), 三谷茂（昭和16 年）氏等に依りて報告せられ就中三谷茂氏は妊 
娠 7 ケ月以後の死産兒及生後間女なく死亡せる 新産兒 650例の剖檢例中例 5 夿發見し詳細なる 組織學的檢菜を加へ, 其の組織像, 發生原因, 發生時期, 發生瀕度閉塞の種類, 並びに爾他臟 器の變化等に關し精細なる論述を篇せり。

本症の發生原因に關しては炎症說, 機械的作 用說, 發育異常說等多種の說あるも私の例の發 生原因は Kerkring 氏の㖪䈉異常說に屬すべき ものと認むるを適當と信する。又私の例の閉塞 發生時期に關しては生理的汗肝臟に於て膽汁の 生成せらるるは妊娠 3 ケ月末なるを以つて本例 飞於て小腸, 大腸の何れの部位に於ても極めて 少量の售汁を認め得るを以て閉塞發生時期は胎 生後半期ならんと推斷し得らる。

成書に羊水過多症の成因の一つとして腸閉塞 症の存在を擧げいる如く先天性十二指腸閒塞症 の場合飞も羊水過多症を伴了事の多きは夙江認 められて居る所であつて, 就中三谷茂氏は完全 なる十二指陽閉塞症に於ては, 多少の差こそあ れ羊水過多症は必發の現象淿して羊水過多症の 認め得ざりしは察万例外に屬すべきものと說き 而も妊娠中羊水過多症の發生時期々其の量飞依 りて閉塞の狀態を略々推測し得るると說かる。 郎ち羊水過多症の早期に發生し而女其の量の多 量なる際は, 十二指腸閉塞部位は盲端に終り索 狀物にて腸管に移行するものか或は腸管の斷絶 せるものなれども，之に反し羊水 過多症の奸娠末期飞發生し, 且つ 其の增加の量の少ないものは, 閉 塞が妊㖘の末期潑發生せる事を想 像し得へくく, 且つ其の閉塞は膜樣 中隔に依る閉塞なる事多しと論述 す。此の閉塞部が盲端に終るや將 又, 膜樣閉塞なるや, 否やは手術 を行ふ上に於て重要なる意義を有 するものなるも，また閉塞部以上 の腸管の蠕動の有無は, 其の手術 の豫後を決定するものであつて下 部腸管㳂紛合術を行ふか,また膜 樣閉塞の膜樣瓣を切除する所詮 意義なし。
私の例に於ても亦羊水は總量 $3500 \mathrm{cc}$ であつ $\tau$, 著明なる過多症を示し, 娃娠中子宫の增大 經過其他飞依り, 本羊水過多症は娃娠末期飞發 生したるものと考へられ, 又剖檢に依り閉塞部 は三谷茂氏の說述せる如く膜樣中隔依りて中 斷せられてるるのを認めた。本症に於ける其の 他の臟器の發育異常は, 諸外國に於て種々報告 せられあるも，本邦に於ての報告は比較的少な く, 僅か儿館繁雄 (昭和10年) 氏が心房中隔缺 如を合併せるを認めたるを報告し，三谷氏に依 りて高度なる空腸の發有不全, 及び閉塞, メッ

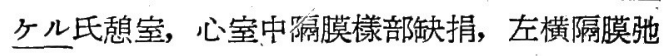
緩症, 左肺缺捐, 二葉右肺臟, 馬蹄型腎, 膽䨢 の著明なる擴張等が報告せられてるる。

私の例飞於ては(1)左䨳胞腎, (2)左肺の分葉 不全, 等の渏形の合併を認めた。

\section{結論}

妊娠末期江羊水過多症を伴ひ, 出生後珈琲殘 渣樣物を吐出しつ১，6 日にして死亡せる 1 女 性新産兒を剖檢し, 其の死亡原因が先天性十二 指腸膜樣閉塞症なる事芝確め, 又左䨳胞腎, 左 肺分葉不全, 等の畸形の存在を認めたり。

稿を終るに當り御校閱の勞を給りたる三谷敎 授に對し深甚の謝意を表す。

第 1 湍

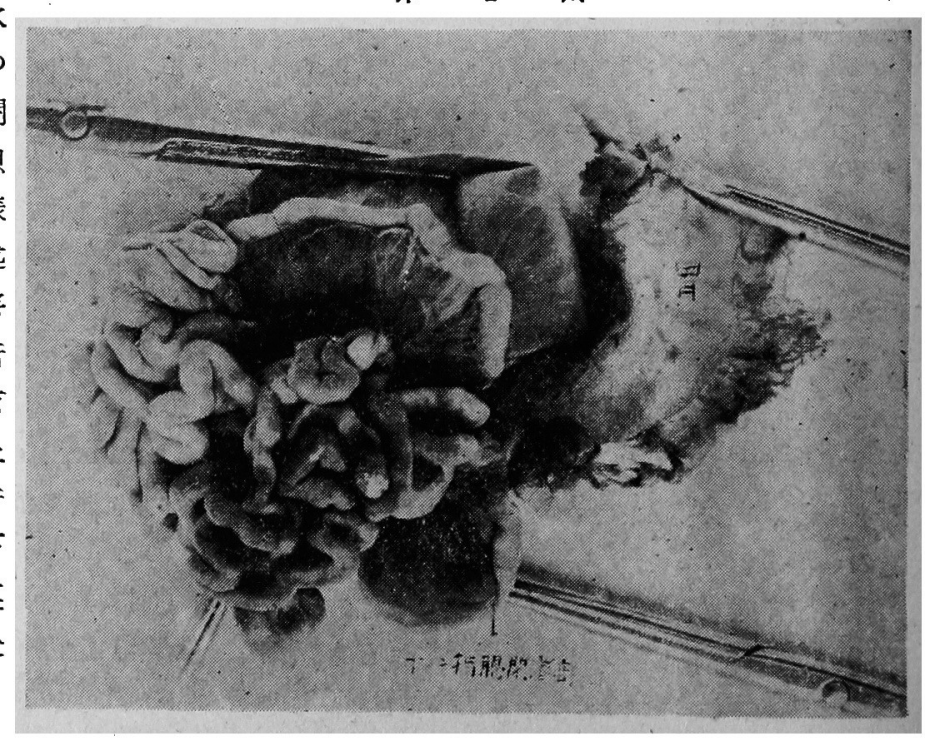




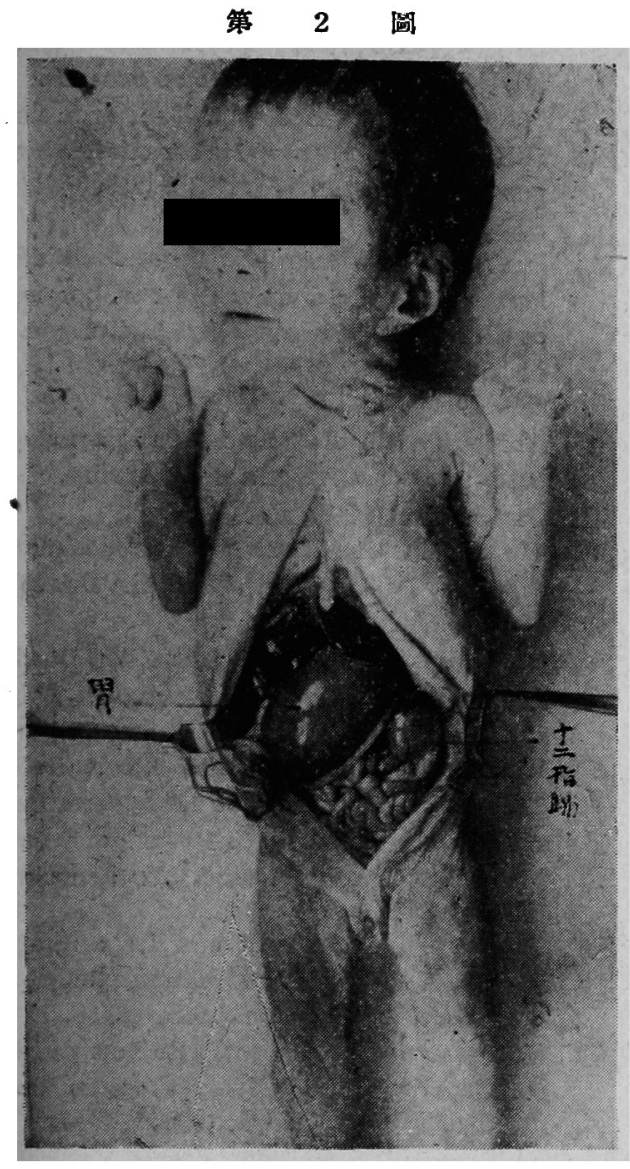

交献

(1) 池田嘉一郎, 先天性腸闒塞症の 1 例, 阔山醫學 會雜誌，第305號，大正 4 年 1 月。

（2）小山武夫, 先天性辩膜漛小腸狄花に就て，兒科 雜誌212號 1 頁, 大正 7 年。

（3）小山武夫, 先天性腸管㷋染の 2 例, 兒科雜誌第 243號371頁改び759頁，大正 9 年。

（4）大梘菊雄, 先天性指腸閉塞の 1 例日本外科學會 雜誌, 簽24回, 第 5 號, 大正12年 8 月。

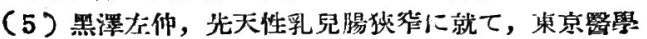
俞雜誌，策36巻，1242頁，大正11年。

（6）佐伯重治, 先天性空腸閉塞, (標本偝覧)。日本 外科學會，第25回，737頁，大正13年。

（7）梅村六郎先天性腸管㺅菅の 1 例, 日本外科學會, 第26回，991頁，大正14年。

（8）中村政司, 先天性十二指腸閉塞症の剖檢例, 臨

床 y.兒科雜誌第 3 巻策 10 號, 昭利 4 年 10 月。

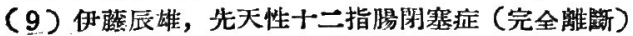

の 1 例, 北越醫學會雜誌 46 巻7號443, 昭和 6 年 7 月。

(10) 田章吾, 先天性小腸狄復病, 東京學事新誌第2710

號, 253頁, 昭和 6 年。

（I1）水野國治, 新生兒先天性晹閘塞症, 近烧産婦人
科學會雜誌 15 巻， 2 號，416, 昭和 7 年 3 月。

（12）二宮溫欣，羊水過外应に於て得たる胎兒の先天 性12指腸閂塞症の 1 例, 北海道眣學會雜誌, 10年 7 號1354頁, 昭和 7 年 7 月。

（13）菊地正三，先天性幽門狭毞症，東北登学會雜誌 第16巻, 病理特㣮第 1,39 頁昭和 8 年。

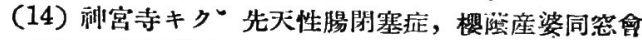
雜誌㓣刊號 68 頁, 昭和 9 年 8 月。

（15）鉿木重大，十二指腸閉塞症に於ける自律种經系 未梢の感受性に就ての藥理學的研究。東京紫學會雜 誌48巻9號1870, 昭和9年9月。

（16）惠美哲夫, 先天性腸閉塞症の 1 例, 兒科雜誌, 820頁, 昭利 9 年。

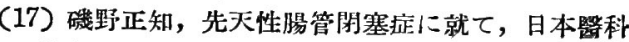
大學雜誌策 5 巻, 65頁, 昭和 9 年 1 月。

（18）三谷茂，先天性十二指腸閂塞症の 5 例，近获産 婦人科學俞雜誌 18 巻 12 號 2108 , 昭利10年12月。

(19) 館繁雄, 先天性十二指腸閂塞症兼心房中隔缺如 症の 1 例。日本婦人科學䈏雜誌 31 巻 4 號, 777 , 昭利 10年 4 月。

(20) 三谷茂，先天性食道閂鎦症の 3 例及び先天性十 二指腸閂鎖症の 5 例, 日本病理學會雜誌， 27 巻 170 , 昭利12年 7 月。

(21) 三谷茂, 新産兒消化管の病理に關する研究, 先 天性十二指腸閉塞症の 5 例, 日本醫科大學䌖誌 11 巻 7 號 1097 , 昭和 15 年 7 月。

（22）稻葉惯。稀有なる先天性十二指晹狄花症の 1 例 及び其のレ緗學的考察診治療28巻119,1151, 昭 和16年11月。

（23）飯淵汃汪る。初生兒腸䦥塞应の 1 剖檢例, 玨事 公論, 1407號 2210 。昭利14年9月。

（24）近藤俊平，十二指腸部先天性塞症の 1 例，産婦 人科紀要 26 巻 5 號 424 , 昭利 18 年 5 月。

（25）野副二三夫，森本昌，先天性畐目部腸閉塞の 1 例, 近幾21巻11號1725面。

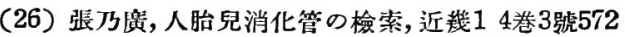
頁。

(27) 富田貞治，新産兒吐乳に就て。東西祭學第 7 巻 2 號97頁 (昭和15年 2 月)

（28）長島三郎, 加藤一郎, 先天性腸閉塞症の 1 例。 産婦人科の世界第 2 巻第 7 號457頁。(炤利 25 年7月)

(1) Hempel; Ein Fall von angeborenen Verschluss des Duodenum. Jahrb. f.Kinderh. N.F.Bd. 6. 1873. S.381.

(2) H.Hauser; Atresia duodeni als Todesursache bei einem Neugeborenen von 7 Tagen. Monatschr. f. Geb. u. Gyn. Bd. 34, 1911, S. 678.

(3) Gärtner: Mutiple Atresien und Neurosen des Darms bei einem Neugebore Knaben Jahrb. f. Kinderh, N.F.Bd. 20, S.403.

(4) Funk Brentano und Deroide: Uber Hämatomesis bei einem Neugeborenen infolge von Atresie des Duodenums. 2bl- 
f. Gyn. 1908, S.539.

(5) Fuss: Demonstration einer Atresia duodeni mit Defektbildung der Flexura duodeno. jejunalis. Ref. Zbl. f.Gyn. 1934, S.1188.

(6) F.Franke; Uber den angeborenen Verschluss des Dünndarms und Seine Behandlung. Archiv f. kl Chir. Bd. 57. 1898, S.591.

(7) C.Fieux: Schwere Pylorusstenosen beim Neugeboren. Ref. Zbl. f. Gyn. 1912, S. 1161.

(8) P.Fockens: Ein operativ geheilter Fall von kongenitaler Dündarmatresie, Zbl, f. Chir. 1911, S.532.

(9) G.Fanconi: Fünf Fälle von angeboren en Darmverschluss, Dünndamatresien, Duodenalstenose, Meconiumileus. Virchows. Archiv, Bd. 229, 1921, S.207.

(10) N.P.Ernst: Atresia infrapapillaris duodeni congenita, Duodeno-Entere anastomose, Heilung. Zbl. f. Chir. Bd. 43, 19 16, S.573,

(11) P.Dreike: Einbeitrage zur Kentniss der Läange des mehschlichen Darmkanals. Zeitschr, f. Chir. Bd. 40, 1894, S.44.

(12) H.Cramer: Neue Gesichtspumkte zur Aetiologie der Hydramion, infolge mangelunder Resorption des Fruchtwasser Monatscher. f. Geb. u Gyn. Bd. 38, 1913, S. 251.

(13) S. Ciechanowski u. L.K.Glinski; Zur Froge der kongenitalen Dünndarmatresie. Virchows Archiv Bd. 196, 1909, S. 168.

(14) R.Bretschneider; Beitrag zur kongeni, taien Dünndarmatresia. Archiv. f. GynBd. 63, 1901, S.209.

(15) H.Brann; Uber den angeborenen Verschluss des Dünndarms und seine Operativer Behandling. Beitrage zur klinische Chirurgie Bd. 34, 1902, S.993.

(16) G.boden: Ein Fall von ftalen Dünndarmverschluss mit Beiträgen' Zur Histologie und Histogenese, Virchows Archiv, Bd.178, 1930, S.529.

(17) Audebert u. Berny: Compt. rend. soc. d'obst. 1907, S.257. cit. H.Hinselman.

(18) H.E.Anders; Die Genese der augeborenen Stenosen und Atresien des menschlichen Darmkanals im Lichte der vergleichenden Entwick=lungsgeschichte. Ergebn, d. Anaton, und Entwicklungsgesch. Bd.26, 1925.
(19) H.E.Anders: Die Stenosen und Atresien des Duodenums, E.Schwalbe. Morphologie der Missbildungen des Menschen und der Tiere, T.3. Kap. 4. S.434.

(20) H.E.Anders; Uber Kloakenmissbildun. gdn. Virchows Archiv, Bd. 229, 1921, S.531.

(21) H.E.Anders: Uber die Entstehung der kongenitalen Dünndarmatresien, besonders des Dünndarms, Verhaudlung d. deut. Path, Gedchel, J. 19. 1923, S. 337.

(22) Ahleeld: Zur Aetiologie der Darmdefecte und der Atresia ani Archiv. f. Gyn. Bd. 5. 1873, S.230.

(23) M.O.Wyss: Uber congenitale Duodenalatresien. Béstroge zur K1. Chir. Bd. 26, 1900, S.631.

(24) C.White: Totaler Verschluss des Duodenums bei einem Neugeboren. Ref. Zbls f. Gyn. 1912, S.1716.

(25) Walz: Zur Diagnose der kongenitale Dünndarmatresien unter besonderer Berückdichtigung der Untersuchung de Meconeums. Münch, med. Wochenschr 1906, S. 1011.

(26) Voron: Uber ein Fall von Imperforation des Duodenums bei einem Nengeb. oren, Ref. Zbl. f. Gyn. 1905, S.158.

(27) D. Veszpremie: Einige Fälle von angeborenem Darmverochluss, Zieglers Beitrage, Bd. 60, 1915, S. 124.

(28) A. Tobeck: Uber angeborene Verschlusse des Darmoöhres (gleichzeitung) ein Beitrag zur Frage der Entrstsehung der Meconium Körperchen Virchows Archiv. Bd. 265, 1927, S.330.

(29) Tandler: Zùr Entwicklungsgeschichte des menschlichen Duodenum in früheren Embrzonalstadien. Morphol. Jahrb. Bd. 29, 1901, S. 187, cit. H.E.Anders.

(30) Taglicht: Ein Eall von zahlreichen Missbildungen bei einer Totgeb $=$ orenen Fhucrt. Virchows Archiv, Bd. 229, 1921, S.303.

(31) Sieber: Duođenalatresée bei Neugeboren. Zbl, f. Gyn, 1912, S.757.

(32) Schriddle: Uber die Epithelproliferationen in der embryonalen menschlichen speiserohre. Virchows Archiv, Bd. 191, 1908, S.178.

(33) H.K.Schmidt: Zur Frage der Sekretion und Resorption des Fruchtwassersund ihrer störung bei Miss bildungen, Monatschr f. Geb. n. Gyn, Bd. 72, 1925, 
S. 1 ,

(34) B.Rosenthal: Uber Duodenalverschluss. Archiv. f. Gyn. Bd. 86, 1908, S. 28.

(35) A.Reuss: Halban-Seity, Biol. n. Path, de. Weibes Bd. 8. T. 2, S. 737.

(35) Preisich: Angeborener doppelter Klappen Verschluss des Duodenums. Ardhiv f. Kinderb. Bd. 57, 1903, 346.

(37) H.Popper: Zur Kentniss des Angeborenen Dickdarmverschluss. Virchows Archiv., Bd. 278, 1930, S. 295.

(38) W.Odermatt: Kongenitale Duodenalatresien, Zeitschr. f. Geb. u. Gyn. Bd. 79, 1917, S. 507.

(39) H.Nahrath: Vier Fälle angeborener Darmverschluss, Virchows Archiv, Bd. 273, 1929, S. 747 .

(40) H.Meyer: Oesophagsatresie und Hydramnion, Zbl. f. Gyn. 1929, S. 1562.

(41) K.Meusburger: Ein Fall von Duodenumatresie in Kombinationmit Defekt des mittleren Oesophagus und des untersten Rectum Sowie Mhhrfache Andere Missbildungen. Virchows Archiv, Bd. 199, 1910, S. 401.

(42) P.Kuliga: Zur Genese der kongenitalen Dünndarmsterosen und Atresien, Zieglers Beiträge, Bd. 33, 1903,S.481.

(43) Kreuter: Zur Aetiologie der kongenitale Atresien des Darmes und Oesophagus, Archiv, f. Kl. Chir. Ed. 88, 1908, S. 303.

(44) G.Krahula; Die Beandlung des Hydram nion für die Lebens=erwartung des $\mathrm{K}$ indes, Monatschm, f. Geb. u. Gyn. Bd. 55, 1921, S. 199.

(45) F.Kermauner; Uber angebarenen Verschlüss des Duodenums, Virchows arehiu. Bd. 267,1912 , S. 348.

(46) K.Katz: Atresie des Duodenu ms mit Verdoppelung des Ductus choledochus und Pankreatices, Virchows Archiv, Bd. 278, 1930.

(47) P.Karpa: Zwei Fälle von Dünndarmatresie. Vircho ws Archiv, Bd. 185, 1906, S. 208.

(48) H. Hivselmann: Halbanseitz, Biologie u. Pathologie des Weibas, Bd. 6. T. 1. S. 388 .

(49) Hess: Ein seltiner Fall von Angeborenen Verschluss des Duodenums und des Rectums, Deut. med. Wochenschr. 1897, S. 218.

(50) Salmann: Uber Congenitale Duodenalatresie Mor. f. Kind 19, 1921, 469.

(51) Forssner: Anatomie undEntwicklungsgeschichte Bd. 34, 14.

(52) Kaufmann: Spezielle path Anatomie.

(53) Aschoff: Path-Anatomie Bd. 2.

(54) V.Redwitz Wilhelm Frehn: Mon. f. Geb. et Gyn, Bd. 45, 8. 426, Uber Kongenitale Darmatresie und Stenose.

(55) Kreuter: Uber die Aetiologie der congenitale Darmatresie, Archiv f. Kl. Chir. Bd. 73,' S. 1009.

\section{クルーケンベルグ氏卵巢腫瘍の一例}

A Case of Krukenberg Tumor of the Ovary

$$
\begin{aligned}
& \text { 日本祭科大學第三醫院産科婦人科教宔 (主任 三谷茂教授指導) } \\
& \text { 研 笲生 三 } \begin{array}{c}
\text { 浦 徹 } \\
\text { Miura Tetsuzo }
\end{array}
\end{aligned}
$$

\section{緒言}

クルーケンベルグ氏卵集腫瘍は 1896 年Friedlich Krukenberg が甫めて, Fibrosarcoma ovarii mucocelluläre carcinomatoides なる 名稱のもとに發表した卵巢惡性腫瘍であつて, 從來極めて稀な疾患とされていたが，近年にな
り病理組織學の進歩と共に多くの報告を見る上 うになつた。余も亦最近この臨牀經過の興味亦 る一例を經驗したので報告する。

\section{害驗 例}

患者 2 回目經産婦, 45 才, 無職。 遺傳的關係 父胃癌にて死亡, 夫10年前37才 